\title{
LETTER TO THE EDITOR \\ CORRECTION TO C. J. SWAIN'S PROGRAM FOR INTERPOLATING IRREGULARLY SPACED DATA
}

The programmed version by Swain of Brigg's method of interpolation as published in Computers \& Geosciences (v. 1, no. 4, 1976) interested me greatly. I tried the program, and to my considerable frustration, it did not work. It seemingly can be made to work by the following two sets of changes. Perhaps some of the other readers will be interested.

If the array size is $1+(\mathrm{L}-1) * \mathrm{~L}$ by $1+(\mathrm{L}-1)^{*} \mathrm{~L}$ and $\mathrm{L}=4$, then the initial iteration is performed on an effectively 4 by 4 array. Thus, all points are in the boundary zone, and fixed by a Dirichlet condition in the program. The value of DUIJ will remain at zero throughout all passes and the program crashes. This can be fixed by moving the statement

\section{IF(DUIJ.LT.DELTA.OR.ITER.GE.500) RETURN}

which occurs just before the end of subroutine ITERAT, move it forward so that it follows immediately after

\section{IF(ITER.EQ.1) GO TO 98.}

that is about 9 lines ahead.

On input at the beginning of the program, the array sizes and XMAX and YMAX are calculated incorrectly. The program forces $\mathrm{N}-1$ and $M-1$ to be divisible by $\mathrm{L}$ but may truncate the map area to do this. A direct correction is as follows:

$$
\begin{aligned}
& \text { DX }=\text { XMAX }- \text { XMIN } \\
& \text { DY = YMAX }- \text { YMIN } \\
& \text { DO } 60 \mathrm{I}=\mathrm{L}, \mathrm{NU}, \mathrm{L} \\
& \text { IF((I*INC).GT.DX) GO TO } 61 \\
& 60 \mathrm{CONTINUE} \\
& 61 \mathrm{~N}=\mathrm{I}+1 \\
& \text { DO } 70 \mathrm{I}=\mathrm{L}, \mathrm{MU}, \mathrm{L} \\
& \mathrm{IF}\left(\left(\mathrm{I}^{*} \mathrm{YINC}\right) \mathrm{GT} . \mathrm{DY}\right) \text { GO TO } 71 \\
& 70 \mathrm{CONTINUE} \\
& 71 \mathrm{M}=\mathrm{I}+1 \\
& \mathrm{DX}=\mathrm{XMIN}+\mathrm{DX} / 2.0 \\
& \mathrm{DY}=\mathrm{YMIN}+\mathrm{DY} / 2.0 \\
& \mathrm{XMIN}=\mathrm{DX}-(\mathrm{N}-1)^{*}(\mathrm{XINC} / 2.0) \\
& \text { XMAX }=\mathrm{DX}+(\mathrm{N}-1)^{*}(\mathrm{XINC} / 2.0) \\
& \text { YMAX }=\mathrm{DY}+(\mathrm{M}-1)^{*}(\mathrm{YINC} / 2.0) \\
& \text { YMIN }=\mathrm{DY}-(\mathrm{M}-1)^{*}(\mathrm{YINC} / 2.0)
\end{aligned}
$$

Needless to say it took considerable work to locate these problems. Once corrected the program seemed to give useful results.

Department of Geography

The University of Michigan

WALDO TOBLER Ann Arbor. MI 48104, U.S.A 